general agreement on concerted action. Where standards were low or absent, proof was not lacking that there was a constant injection of infested commodities into the trade stream. At the outset it was recognized that control of the condition of the country's imports would have to commence in the countries of export, and that the aid of Government was necessary. It was also recognized as a first essential in that direction that definite indication should be given that the house here was being put in order. The most important and easiest step was that ordinary principles of cleanliness should be inculcated. This could be achieved largely by the exercise of commercial prudence. The owner of the commodity and the owner of the structure or equipment could be more mindful of their duty to each other, and the force of competition could be used to raise standards. Restraint on landing and isolation of fouled commodities again were really matters of commercial prudence, but as the most desirable precautions, if left to voluntary effort, could be offset by the recalcitrant or indifferent, something more substantial than the play of commercial prudence was needed. There remained the respective parts of the applied biologist and the chemist. Control of infestation of stocks or structures necessitated prolonged research. In this respect it was fortunate for the conference that these very matters had for a long time past been the special preoccupation of the Stored Products Laboratory of the Imperial College of Science and Technology; although it was to be regretted that that work in more recent times had suffered greatly and been circumscribed by lack of recognition.

The conference laid its problem before the Government early in 1938, and by the end of that year, decision had been taken for the establishment of a permanent research and advisory organization under the Department of Scientific and Industrial Research, industry making substantial grants towards the cost. The Department accepted the generous offer of the Imperial College to place the Stored Products Laboratory at Slough available, and the new organization inherits the benefit of the past work of the laboratory. The Department also established the Standing Conference of Co-operating and Contributing Industrial Organisations, and appointed as its chairman Mr. W. McAuley Gracie, the chairman of the former informal conference and the initiator of the industrial effort. Prof. J. W. Munro, the former director of the laboratory, has become the consultant to the Department, whilst retaining his chair in the College. This desirable conjunction of science and industry was effected prior to, and the organization was available at, the outbreak of war. In the course of the industrial investigations it has become apparent that immediate attention should be given to the establishment of a comprehensive case for guidance in production, research and application as relating to insecticides, fungicides, raticides and repellents for all purposes. Several scientific advisers to and in Government Departments have been consulted, and they fully agree as to this. Certain sectional pieces of work have been done, and available in- formation can be lifted out of dormancy, but there are gaps to be filled and a general harmony to be established, so that economic decisions may be taken and lines of research indicated. Mr. Gracie has requested Mr. W. V. Blewett, who has been released by Imperial Chemical Industries, Ltd., for this purpose, to carry out at once an economic and technical survey of the demand and production of these materials, with special reference to the potentialities and requirements of the British Empire and friendly States. Communications should be addressed to $\mathrm{Mr}$. Blewett, at 42 Hamilton House, 155 Bishopsgate, London, E.C.2.

\section{The Universities and Man-Power}

Ax the annual meeting of the Court of Governors of the University of Birmingham, the Vice-Chancellor, Dr. Raymond Priestley, paid a tribute to the attitude of the Government in recognizing the importance of the part the universities can play in the war-time economy of Great Britain. This has been directed towards the avoidance of the waste of young men of high educational attainment and intellectual promise which was so lamentably characteristic of the War of 1914-18. Dr. Priestley regards this attitude as "one of the few signs of progress we can see in a backslidden generation". But in the last few weeks, things have taken a turn for the worse. In times of crisis, when the immediate needs fill the foreground, there is a real danger that we may take a too shortsighted view. The stream of science, and applied science, graduates has so far been undammed; the trouble here is the great increase in the demand. But Dr. Priestley wonders now whether we have been wise in diminish. ing the flow of graduates in commerce, art, and law. The Government clearly has not changed its university policy, and intends to safeguard the situation as well and as promptly as it can.

"The real menace to our future is the air training scheme. No one in his senses will grudge to the R.A.F. to-day the lion's share of the flower of the nation's youth. Nevertheless, this scheme, reaching, as it does, right down into the schools, is the real danger the universities face to-day. Its success is a measure of the essential soundness, the grit, the adventurous spirit and the imagination of British youth. But this does not decrease the universities' dilemma, as they foresee the loss of their raw material for 1942 and later war years. Some of these lads, outstanding in character and intellect, who are to. day flocking to the R.A.F., should be saved from their own enthusiasm. For the sake of the nation's future, they should be directed into the universities".

\section{Government Grant to Universities}

Speaking in reply to a question by Mr. K. W. M. Pickthorn (University of Cambridge), Sir Kingsley Wood, Chancellor of the Exchequer, recalled that, in view of the vital part played by the universities in the life of the community, the importance of main. taining so far as possible the standards of university education and the essential contribution which the universities are making in a variety of ways towards 